\title{
Evaluation of models utilized in in vitro gas production from tropical feedstuffs ${ }^{1}$
}

\author{
Avaliação de modelos utilizados na produção de gás in vitro de \\ alimentos tropicais
}

\author{
Ícaro dos Santos Cabral2*; José Augusto Gomes Azevêdo ${ }^{3}$; Douglas dos Santos \\ Pina $^{4}$; Luiz Gustavo Ribeiro Pereira ${ }^{5}$; Henrique Jorge Fernandes ${ }^{6}$; \\ Flávio Moreira de Almeida ${ }^{7}$; Lígia Lins Souza ${ }^{3}$; Ronaldo Francisco de Lima; \\ Luís Gabriel Alves Cirne ${ }^{8}$
}

\begin{abstract}
This study aimed to evaluate the adequacy of seven non-linear models (France, Orskov and McDonald, Gompertz, exponential, logistic, two-pool exponential and two-pool logistic) in the adjustment of the curve and in the generation of parameters of cumulative gas production from five tropical feedstuffs (rice hulls, sugarcane, cassava chips, turnip by-product, and peach-palm by-product) used in ruminant nutrition. To this end, the feedstuffs were incubated in vitro in graduated glass syringes together with a buffer inoculum solution, in triplicate. Gas production was read at $0,2,4,6,8,10,12,24,26,28$, $30,32,36,48,52,54,56,60$ and $72 \mathrm{~h}$ of incubation. The data were used to generate the parameters of each model using the SAS statistical package. After the parameters were generated, the gas volume values were obtained at the aforementioned times, for each model, and these were compared with the values observed at incubation by using Model Evaluation System (MES) software. For the comparison, regression parameters were tested using Mayer's test, in addition to the evaluation of the mean bias (MS), concordance correlation coefficient (CCC), and mean squared prediction error (MSPE). The France, Logistic, and Gompertz models, for rice hulls, and the Orskov and McDonald model, for cassava chips, were significant $(\mathrm{P}<0.1)$ according to Mayer's test, indicating lack of fit of the model. Besides presenting the lowest MSPE, the models that showed fit according to Mayer's test were the two-pool logistic for rice hulls and cassava chips, and the two-pool exponential for sugarcane, turnip, and peach palm. Thus, the non-linear two-pool models are the most efficient in adjusting to the curve and in the generation of parameters of cumulative production of gases from the tested feedstuffs.
\end{abstract}

Key words: Degradation kinetic. Evaluation of feedstuffs. Non-linear models.

1 Parte da Tese de Doutorado do primeiro autor pelo Programa de Pós-Graduação em Zootecnia, Universidade Estadual do Sudoeste da Bahia, UESB.

2 Prof., Universidade Federal do Oeste do Pará, UFOPA, Santarém, PA, Brasil. E-mail: i.s.cabral@hotmail.com

3 Profs., Universidade Estadual de Santa Cruz, UESC, Ilhéus, BA, Brasil, E-mail: zeguto00@gmail.com; ligia_lins@yahoo. com.br

4 Prof., Universidade Federal da Bahia, UFBA, Salvador, BA, Brasil. E-mail: douglaspinaufba@gmail.com

5 Pesquisador, Empresa Brasileira de Pesquisa Agropecuária, EMBRAPA Gado de Leite, Juiz de Fora, MG, Brasil. E-mail: luiz. gustavo@embrapa.br

6 Prof., Universidade Estadual de Mato Grosso do Sul, UEMS, Aquidauana, MS, Brasil. E-mail: henrique@zootecnista.com.br

7 Prof., Centro Universitário de Patos de Minas, UNIPAM, Patos de Minas, MG, Brasil. E-mail: flavioma@unipam.edu.br

8 Profs., Universidade Federal do Oeste do Pará, UFOPA, Santarém, PA, Brasil. E-mail: ronaldofranciscolima@yahoo.com.br; lgabrielcirne@hotmail.com

* Author for correspondence

Received: Apr. 20, 2018 - Approved: July 10, 2018

Semina: Ciências Agrárias, Londrina, v. 40, n. 1, p. 443-456, jan./fev. 2019 


\title{
Resumo
}

\begin{abstract}
Objetivou-se avaliar a adequação de sete modelos não lineares (France, Orskov \& McDonald, Gompertz, exponenciais simples e bicompartimental e logísticos simples e bicompartimental) no ajuste da curva e na geração de parâmetros de produção cumulativa de gases de cinco alimentos tropicais (casca de arroz, cana-de-açucar, raspa de mandioca, resíduo de nabo e resíduo da pupunha) utilizados na nutrição de ruminantes. Para tal, realizou-se a incubação in vitro, em triplicata, dos alimentos em seringas de vidro graduadas junto com solução tamponada de inoculante. A leitura da produção de gás foi realizada nos tempos $0,2,4,6,8,10,12,24,26,28,30,32,36,48,52,54,56,60$ e 72 horas. Os dados gerados foram utilizados para geração dos parâmetros de cada modelo testado com auxílio do pacote estatístico SAS. Após a geração dos parâmetros foram obtidos valores de volume de gás nos tempos supracitados, para cada modelo, e estes foram comparados aos valores observados na incubação através do programa Model Evaluation System (MES). Para comparação, testou-se os parâmetros de regressão pelo teste de Mayer, além da avaliação dos valores de viés médio (VM), coeficiente de concordância da correlação (CCC) e quadrado médio do erro de predição (QMEP). Os modelos de France, Logístico e Gompertz, para casca de arroz, além do modelo de Orskov \& McDonald, para raspa de mandioca, foram significativos $(\mathrm{P}<0,1)$ ao teste de Mayer, indicando falta de ajuste do modelo. Os modelos que apresentaram ajuste segundo o teste de Mayer, além de apresentarem os menores QMEP, foram o Logístico Bicompartimental para a casca de arroz e raspa de mandioca e o Exponencial Bicompartimental para cana-de-açucar, nabo e pupunha. Sendo assim, os modelos não lineares bicompartimentais são os mais eficientes no ajuste da curva e na geração de parâmetros de produção cumulativa de gases dos alimentos testados
\end{abstract}

Palavras-chave: Avaliação de alimentos. Cinética de degradação. Modelos não lineares.

\section{Introduction}

The in vitro gas production technique has been widely used to evaluate the kinetic of the rumen microbial fermentation processes (RAMIN; HUHTANEN, 2012; KRIZSAN et al., 2013; LI et al., 2014). Among the in vitro technique, this method is less costly, requires less time to generate results, provides a greater control of experimental conditions, and is easily replicated (GETACHEW et al., 1998). The technique is based on the assumption that the production of gas in a growth medium inoculated with rumen microorganisms and under conditions similar to those of the reticulorumen (temperature, $\mathrm{pH}$, and anaerobiosis) is directly proportional to the amount of fermented substrate (LÓPEZ et al., 2007). When testing food by the in vitro gas production technique, it is expected that foods that produced more gas will be better utilized by ruminant animals, thus increasing animal production.

The application of the values of gases produced in non-linear models results in the estimation of parameters such as degradation rate and gas volume resulting from the degradation of each nutrient, mainly the fibrous and non-fibrous carbohydrates, and the latency time (lag phase) of the fermentation process (SCHOFIELD et al., 1994). The use of these models provides additional information in addition to the total volume of gases produced during incubation.

Several non-linear models (FRANCE et al., 2005; MELLO et al., 2008; RODRIGUES et al., 2009; UCKARDES et al., 2013; UCKARDES; EFE, 2014), with different assumptions and treatments, are available for the adjustment of gas production curves and to determine the degradation parameters or the fermentation profile. The main objective of these models is to describe alterations in the system as a function of the incubation time, however, the conditions for obtaining these equations, especially for the substrates used, may result in inadequate use in tropical foods, generally with a higher content of fibrous carbohydrates, which results in slower gas production, altering the parameters of degradation rates. 
Among the non-linear models utilized in the mathematical description of the gas production profiles, the exponential growth and sigmoid models stand out; these assume that the specific gas production rate can be proportional to the amount of substrate and independent of the microbial mass, independent of the amount of substrate and proportional to the microbial mass, or proportional to the amount of substrate and microbial mass (SCHOFIELD et al., 1994). Additionally, the models can comprise one, two, or more compartments and/ or fermentation stages.

This study aimed to evaluate the adequacy of different mathematical models to adjust the profiles of kinetic of in vitro gas production from tropical feedstuffs.

\section{Material and Methods}

The experiment was carried out in the Laboratory of Animal Nutrition at Universidade Estadual de Santa Cruz (UESC), located in Ilheus - BA, Brazil.

Samples of rice hulls, sugarcane, cassava chips, peach-palm by-product, and turnip by-product were pre-dried at $55{ }^{\circ} \mathrm{C}$ for $72 \mathrm{~h}$ and ground through a knife mill with $2 \mathrm{~mm}$ pore size for later analyses of the dry matter $(\mathrm{DM})$, crude protein $(\mathrm{CP})$, mineral matter (MM), ether extract (EE), and acid detergent fiber (ADF) contents, according to AOAC (1990) methods.

In the analyses of neutral detergent fiber (NDF), the samples were treated with heat-stable alpha-amylase, without using sodium sulfide, and corrected for the residual ash (MERTENS, 2002). The correction of NDF and ADF for the nitrogen compounds and the estimate of the neutral (NDIN) and acid (ADIN) detergent insoluble nitrogen compounds were performed as described by Licitra et al. (1996). Lignin contents were obtained by solubilizing the cellulose in sulfuric acid (VAN SOEST; ROBERTSON, 1985).

The non-fiber carbohydrates (NFC) content was calculated according to Hall (2000): NFC $=100-$ (NDFap - CP - EE - MM), where NDFap is the NDF corrected for ash and protein.

Total digestible nutrients (TDN) were estimated based on the chemical composition of the samples of the feedstuffs according to equations proposed by NRC (2001).

The in vitro digestion of NDF (IVDNDF) was performed according to Schofield et al. (1994), using 50-mL Wheaton bottles previously washed with distilled water and dried in an oven at $105^{\circ} \mathrm{C}$.

The buffer solution, described by Menke and Steingass (1988), was prepared and heated to 39 ${ }^{\circ} \mathrm{C}$, under continuous gasification with $\mathrm{CO} 2$. For the inoculation, rumen fluid was collected from a castrated rumen-fistulated male cattle fed a diet containing $70 \%$ roughage and $30 \%$ concentrate.

The rumen fluid was collected manually in the morning, before the feed was supplied, stored in thermos previously heated $\left(39^{\circ} \mathrm{C}\right)$, and immediately taken to the laboratory. In an air-conditioned room at $39{ }^{\circ} \mathrm{C}$, the rumen fluid was filtered, passing through two layers of cotton fabric (gauze). Subsequently, the buffer solution $(1: 1 \mathrm{v} / \mathrm{v})$ was added to the rumen fluid, under continuous injection of $\mathrm{CO} 2$.

Each bottle received approximately $200 \mathrm{mg}$ DM of each feedstuff to be tested and $30 \mathrm{~mL}$ of the buffered rumen fluid and were sealed immediately with rubber stoppers and kept at a temperature of 39 ${ }^{\circ} \mathrm{C}$. Three bottles were used per feedstuff.

After $48 \mathrm{~h}$ of incubation, bottles were removed from the air-conditioned room and transferred to a refrigerator at $4{ }^{\circ} \mathrm{C}$ to stop the fermentation process. The content of each bottle was later filtered in a filter crucible, subjected to a neutral detergent solution (MERTENS, 2002), and autoclaved for $60 \mathrm{~min}$ at $105{ }^{\circ} \mathrm{C}$, according to the technique proposed by Pell and Schofield (1993). After autocleavage, the entire content was filtered once again in the same filter crucible, washed with distilled warm water and acetone, and dried in an oven at $105^{\circ} \mathrm{C}$ for $16 \mathrm{~h}$. 
The chemical composition, IVNDF, and TDN values are shown in Table 1.

For gas production, calibrated syringes were used according to a procedure described by Getachew et al. (2004).
Three syringes were used per feedstuff. Each syringe received approximately $200 \mathrm{mg}$ DM of each feedstuff to be tested and $30 \mathrm{~mL}$ of the buffered rumen fluid described previously. With the tip of the syringe closed, the initial volume was recorded and the syringe was heated to $39^{\circ} \mathrm{C}$.

Table 1. Chemical composition, in vitro digestibility of neutral detergent fiber (IVDNDF) and total digestible nutrients (TDN) of the evaluated feedstuffs.

\begin{tabular}{lccccc}
\hline Feedstuff & Rice hulls & Sugarcane & Cassava chips & Turnip by-product & Peach palm by-product \\
\hline $\mathrm{DM}^{\mathrm{a}}$ & 919 & 235 & 918 & 916 & 865 \\
$\mathrm{OM}^{\mathrm{b}}$ & 839 & 952 & 949 & 943 & 950 \\
$\mathrm{CP}^{\mathrm{b}}$ & 21 & 31 & 29 & 276 & 60 \\
$\mathrm{NDIN}^{\mathrm{c}}$ & 917 & 315 & 242 & 199 & 243 \\
$\mathrm{ADIN}^{\mathrm{c}}$ & 599 & 176 & 160 & 187 & 118 \\
$\mathrm{EE}^{\mathrm{b}}$ & 7 & 10 & 12 & 243 & 13 \\
$\mathrm{NDFap}^{\mathrm{b}}$ & 691 & 488 & 175 & 227 & 578 \\
NFC $^{\mathrm{b}}$ & 120 & 425 & 732 & 197 & 299 \\
$\mathrm{ADFp}^{\mathrm{b}}$ & 751 & 296 & 202 & 145 & 389 \\
LIG $^{\mathrm{b}}$ & 199 & 49 & 43 & 75 & 30 \\
IVDNDF $^{\mathrm{d}}$ & 91 & 600 & 875 & 816 & 714 \\
$\mathrm{TDN}^{\mathrm{b}}$ & 275 & 683 & 744 & 676 & 643 \\
\hline
\end{tabular}

${ }^{\mathrm{a}} \mathrm{g} / \mathrm{kg} ;{ }^{\mathrm{b}} \mathrm{g} / \mathrm{kg} \mathrm{DM} ;{ }^{\mathrm{c}} \mathrm{g} / \mathrm{kg} \mathrm{CP} ;{ }^{\mathrm{d}} \mathrm{g} / \mathrm{kg}$ NDFap.

Reading times were $0,2,4,6,8,10,12,24,26$, $28,30,32,36,48,52,54,56,60$, and $72 \mathrm{~h}$, with the gases volumes recorded in each reading and the syringe slightly shaken.

Results were corrected for the blank (syringe containing buffered rumen fluid, without the sample), and Tifton grass hay was used as standard, at $24 \mathrm{~h}$ of incubation.
The rate and extent of gas production were estimated for each feedstuff by adjusting the gas production data to the one-compartment France et al. (1993), exponential, logistic, Gompertz, and Orskov and McDonald (1979) models, besides the two-pool logistic and exponential models, described in table 2. For the generation of fermentation kinetics parameters, the values observed in the different syringes were considered repetitions and analyzed individually. 
Table 2. Non-linear models evaluated.

\begin{tabular}{|c|c|c|}
\hline Models & Restrictions $^{\mathrm{a}}$ & Equations \\
\hline France et al. (1993) & $\mathrm{A}, \mathrm{b}, \lambda \geq 0$ and $\mathrm{c} \geq-2 \mathrm{~b} \sqrt{T}$ & $\left.\hat{\mathrm{Y}}=\mathrm{A}\left\{1-\exp ^{[-\mathrm{b}(\mathrm{t}-\lambda)-\mathrm{c}}(\sqrt{t} \cdot \sqrt{\lambda})\right]\right\}$ \\
\hline Exponential & $\mathrm{A}, \mu$ and $\lambda \geq 0$ & $\hat{\mathrm{Y}}=\mathrm{A}\left\{1-\exp ^{[-\mu(t-\lambda)]}\right\}$ \\
\hline Logistic & $\mathrm{A}, \mu$ and $\lambda \geq 0$ & $\hat{\mathrm{Y}}=\mathrm{A} /\left\{1+\exp ^{[2-4 \mu(\mathrm{t}-\lambda)]}\right\}$ \\
\hline Gompertz & $\mathrm{A}, \mu$ and $\lambda \geq 0$ & $\hat{\mathrm{Y}}=\mathrm{A} \exp ^{\{-\exp [1-\mu(t-\lambda)]\}}$ \\
\hline Orskov e McDonald (1979) & A and $\mu \geq 0$ & $\hat{Y}=A\left\{1-\exp ^{[-\mu t]}\right\}$ \\
\hline Two-pool exponential & ANFC, AFC, $\mu$ NFC, $\mu \mathrm{FC}$ and $\lambda \geq 0$ & $\begin{array}{c}\hat{Y}=\operatorname{ANFC}\left\{1-\exp ^{[-\mu N F C(t-\lambda)]]}\right\}+\operatorname{AFC}\{1- \\
\left.\exp ^{[-\mu F C(t-\lambda)]}\right\}\end{array}$ \\
\hline Two-pool logistic & ANFC, AFC, $\mu$ NFC, $\mu \mathrm{FC}$ and $\lambda \geq 0$ & $\begin{array}{c}\hat{\mathrm{Y}}=\mathrm{ANFC} /\left\{1+\exp ^{[2-4 \mu \mathrm{NFC}(\mathrm{t}-\lambda)]}\right\}+\mathrm{AFC} /\{ \\
\left.1+\exp ^{[2-4 \mu \mathrm{FC}(\mathrm{t}-\lambda)]}\right\}\end{array}$ \\
\hline
\end{tabular}

${ }^{a} \mathrm{~A}=$ asymptote $(\mathrm{mL}), \mathrm{ANFC}=$ asymptote of non-fibrous carbohydrates $(\mathrm{mL}), \mathrm{AFC}=$ asymptote of fibrous carbohydrates $(\mathrm{mL}), \mu=$ fractional rate of degradation $\left(\mathrm{h}^{-1}\right), \mu \mathrm{NFC}=$ fractional rate of degradation of non-fibrous carbohydrates $\left(\mathrm{h}^{-1}\right), \mu \mathrm{FC}=$ fractional rate of degradation of fibrous carbohydrates $\left(\mathrm{h}^{-1}\right), \mathrm{t}=$ incubation time $(\mathrm{h}), \lambda=$ lag time $(\mathrm{h}), \mathrm{b}\left(\mathrm{h}^{-1}\right)$ and $\mathrm{c}\left(\mathrm{h}^{-1 / 2}\right)$ without biological significance.

The following equation was used to obtain the fractional degradation rate $(\mu)$ of the model of France et al. (1993):

$$
\mu=b+c / 2, t \geq \lambda
$$

The parameters of the models were adjusted by non-linear regression by the Gauss-Newton interactive method, adopting the PROC NLIN procedure of SAS (SAS INSTITUTE, 2008).

After generation of the parameters $(\mathrm{A}, \mu$ and $\lambda)$, the volume of gases produced in the different periods was estimated from each model and these data were compared to the average of the values observed in the 3 syringes of each evaluated food. In the bicompartmental models the value of A was obtained by the sum of ANFC and AFC.

Models were evaluated by adjusting the simple linear regression model of the observed values to the predicted values by the equations. The estimates of the regression parameters tested by the joint null hypothesis followed Mayer et al. (1994):

$$
\text { Ho: } \beta 0(\text { intercept })=0 \text { and } \beta 1(\text { slope })=1
$$

Ha: non Ho.
For the Mayer test, the probability level of 0.1 was adopted to increase the stiffness of the evaluation because $\mathrm{P}$-value $<0.1$ was considered significant, i.e. $\beta 0 \neq 0$ or $\beta 1 \neq 1$, in this way the value estimated by the equation is different from that observed in the syringes. In the case of nonrejection of the null hypothesis $(\beta 0=0$ and $\beta 1=$ $1, \mathrm{P}>0.1$ ), the predicted and observed values were considered equivalent.

Additionally, the mean bias (MB) was evaluated, calculated according (COCHRAN; COX, 1957) to the equation given below:

$$
M B=\frac{1}{n} \sum_{i=1}^{n}(x i-y i)
$$

Where $\mathrm{x}=$ observed values; $\mathrm{y}=$ predicted values.

The concordance correlation coefficient (CCC), also known as reproducibility index, which considers exactness and precision simultaneously, was calculated according to Lin (1989).

The comparative evaluation of the efficiency of prediction of the equations was undertaken by analyzing the mean squared prediction error 
(MSPE), as described by Bibby and Toutenburg (1977), according to the equation below:

$$
M S P E=\frac{1}{n} \sum_{i=1}^{n}(x i-y i)^{2}
$$

Where: $\mathrm{x}=$ observed values; $\mathrm{y}=$ predicted values.

Model Evaluation System (MES) software version 3.0.11 (http://nutritionmodels.tamu.edu/ mes.htm, College Station, TX, USA) (TEDESCHI, 2006) was used for the evaluation of the regression parameters, MB, CCC, and MSPE.

\section{Results and Discussion}

The degradation kinetic parameters estimated by the different models are shown in Table 3.

In France model, only the values of $\mathrm{A}, \mu$, and $\lambda$ were presented, since the $\mathrm{b}$ and $\mathrm{c}$ values, present in the equation, besides not having a biological interpretation (FONDEVILA; BARRIOS, 2001), showed negative values for the feedstuffs rice hulls and cassava chips. Even with this difficulty in the interpretation of the data, the France model has still been used to determine the kinetic parameters of in vitro fermentation of high grain diets (JIAO et al., 2018).

Table 3. Total, NFC, and FC, asymptotes, $\left(\mathrm{A}, \mathrm{A}_{\mathrm{NFC}}\right.$, and $\mathrm{A}_{\mathrm{FC}}$, in $\left.\mathrm{mL} / \mathrm{g}\right)$; total, $\mathrm{NFC}$, and $\mathrm{FC}$ fractional degradation rates $\left(\mu, \mu_{\mathrm{NFC}}\right.$, and $\mu_{\mathrm{FC}}$, in $\left.\mathrm{h}^{-1}\right)$; and lag time $(\lambda$, in $\mathrm{h})$ of the feedstuffs tested using different mathematical models.

\begin{tabular}{|c|c|c|c|c|c|c|c|}
\hline \multirow{2}{*}{ Parameter } & \multicolumn{7}{|c|}{ Models $^{\mathrm{a}}$} \\
\hline & 1 & 2 & 3 & 4 & 5 & 6 & 7 \\
\hline \multicolumn{8}{|c|}{ Rice hulls } \\
\hline A & -- & 4.424 & 4.431 & -- & 4.151 & 4.169 & 4.447 \\
\hline $\mathrm{A}_{\mathrm{NFC}}$ & 2.522 & -- & -- & 4.292 & -- & -- & -- \\
\hline $\mathrm{A}_{\mathrm{FC}}$ & 1.916 & -- & -- & 1.361 & -- & -- & -- \\
\hline$\mu$ & -- & 0.055 & 0.054 & -- & 0.035 & 0.105 & 0.053 \\
\hline$\mu_{\mathrm{NFC}}$ & 0.058 & -- & -- & 0.055 & -- & -- & -- \\
\hline$\mu_{\mathrm{FC}}$ & 0.018 & -- & -- & 0.002 & -- & -- & -- \\
\hline$\lambda$ & 0.523 & 0.014 & 0.018 & 0.018 & 0.002 & 0.002 & -- \\
\hline \multicolumn{8}{|c|}{ Sugarcane } \\
\hline A & -- & 45.793 & 42.134 & -- & 41.030 & 41.140 & 42.134 \\
\hline $\mathrm{A}_{\mathrm{NFC}}$ & 24.933 & -- & -- & 24.732 & -- & -- & -- \\
\hline $\mathrm{A}_{\mathrm{FC}}$ & 20.213 & -- & -- & 24.135 & -- & -- & -- \\
\hline$\mu$ & -- & 0.093 & 0.126 & -- & 0.086 & 0.248 & 0.126 \\
\hline$\mu_{\mathrm{NFC}}$ & 0.244 & -- & -- & 0.502 & -- & -- & -- \\
\hline$\mu_{\mathrm{FC}}$ & 0.024 & -- & -- & 0.030 & -- & -- & -- \\
\hline$\lambda$ & 1.346 & 0.788 & 0.001 & 1.387 & 0.001 & 0.001 & -- \\
\hline \multicolumn{8}{|c|}{ Cassava chips } \\
\hline A & -- & 69.262 & 69.264 & -- & 68.034 & 68.277 & 70.639 \\
\hline $\mathrm{A}_{\mathrm{NFC}}$ & 43.936 & -- & -- & 64.743 & -- & -- & -- \\
\hline $\mathrm{A}_{\mathrm{FC}}$ & 26.111 & -- & -- & 14.269 & -- & -- & -- \\
\hline$\mu$ & -- & 0.138 & 0.139 & -- & 0.090 & 0.248 & 0.099 \\
\hline$\mu_{\mathrm{NFC}}$ & 0.176 & -- & -- & 0.155 & -- & -- & -- \\
\hline$\mu_{\mathrm{FC}}$ & 0.037 & -- & -- & 0.008 & -- & -- & -- \\
\hline$\lambda$ & 2.781 & 1.769 & 1.769 & 1.843 & 1.663 & 1.488 & -- \\
\hline
\end{tabular}


continuation

\begin{tabular}{lccccccc}
\hline & & \multicolumn{7}{c}{ Turnip by-product } & & & \\
$\mathrm{A}$ & -- & 37.959 & 36.788 & -- & 36.029 & 36.141 & 36.861 \\
$\mathrm{~A}_{\mathrm{NFC}}$ & 23.575 & -- & -- & 30.042 & -- & -- & -- \\
$\mathrm{A}_{\mathrm{FC}}$ & 13.920 & -- & -- & 9.515 & -- & -- & -- \\
$\mu$ & -- & 0.116 & 0.123 & -- & 0.079 & 0.226 & 0.119 \\
$\mu_{\mathrm{NFC}}$ & 0.130 & -- & -- & 0.173 & -- & -- & -- \\
$\mu_{\mathrm{FC}}$ & 0.031 & -- & -- & 0.027 & -- & -- & -- \\
$\lambda$ & 0.529 & 1.099 & 0.198 & 0.662 & 0.001 & 0.001 & -- \\
\hline & & & Peach palm by-product & & & \\
$\mathrm{A}$ & -- & 104.000 & 96.581 & -- & 94.197 & 94.427 & 96.582 \\
$\mathrm{~A}_{\mathrm{NFC}}$ & 54.356 & -- & -- & 47.915 & -- & -- & -- \\
$\mathrm{A}_{\mathrm{FC}}$ & 45.764 & -- & -- & 55.020 & -- & -- & -- \\
$\mu$ & -- & 0.094 & 0.119 & -- & 0.080 & 0.229 & 0.119 \\
$\mu_{\mathrm{NFC}}$ & 0.181 & -- & -- & 0.412 & -- & -- & -- \\
$\mu_{\mathrm{FC}}$ & 0.029 & -- & -- & 0.051 & -- & -- & - \\
$\lambda$ & 0.767 & 0.891 & 0.001 & 1.039 & 0.001 & 0.001 & - \\
\hline
\end{tabular}

${ }^{\mathrm{a}} 1$ = Two-pool logistic; 2 = France et al. (1993); 3 = Exponential; $4=$ Two-pool exponential; 5 = Logistic; $6=$ Gompertz; $7=$ Orskov e McDonald (1979).

Among the one-compartment models, the Gompertz model appears to overestimate the degradation rate for all evaluated feedstuffs, with a value biologically hard to occur. The onecompartment model showed the lowest $\mathrm{A}$ and $\mu$ values, apparently underestimating them.

In the two-pool models, the asymptote values originating from the NFC were higher in all feedstuffs. This happened because the incubation period was short allowing gas production mainly of NFC. As FC have a slower rate of degradation, as can be seen in Table 3, the larger volume of gases from the FC would occur in later periods. This behavior is presented by Almeida et al. (2015) with incubation of cocoa husks that observed that the gases from the degradation of the NFC reached asymptote in period near the 12 hours of incubation while the volume of the gases from the degradation of the FC continued increasing beyond the 120 hours. Similarly, Benedeti et al. (2018) observed that the asymptote of the gases from the starch fermentation was reached until 12 hours while corn continued its production beyond 48 hours.
For the sugarcane and peach palm, the France model showed the highest asymptote, while for the other feedstuffs the Orskov and McDonald (1979) model, without lag time, had the highest asymptote.

Although the studied feedstuffs showed a greater concentration of FC than NFC, except for the cassava chips, there seems to be limitations in the use of these FC. This limitation interfered with the degradation rates of the FC of all feedstuffs, which did not exceed $0.051 \mathrm{~h}-1$, obtained with the peach palm. For insoluble components, associated with the cell wall fraction of the feedstuffs, the fractional degradation rate is slower when chemical substances or structural barriers are found (GROOT et al., 1996). The crystallinity of the cellulose and the toxic action of phenolic compounds from the cell wall may impose barriers to digestion (CORNU et al., 1994).

Not all models utilized in the gas production kinetics reported in the literature take into consideration the lag time. Factors affecting the duration of lag include the nature of the feedstuff 
incubated, the microbial species inoculated, and the quantity of inoculum added (LÓPEZ et al., 2007). In the adjustment of the functional forms, parameters can be included or removed from the models (UCKARDES, 2013); in this way, the lag can be simply suppressed from the equation if it does not significantly improve the adjustment of the curve, except in the case of the generalized Mitscherlich model (France's growth function), in which, despite small, the lag is necessary to prevent mathematical discontinuity in parameter $\mu$ at incubation time zero.

The regression parameters, the $\mathrm{P}$-value for the Mayer et al. (1994) test, the MB, the CCC, and the MSPE between the observed values and the values estimated by the different mathematical models for the tested feedstuffs are presented in Table 4.
The Mayer et al. (1994) test indicated lack of fit $(\mathrm{P}<0.1)$ for the France, simple logistic, and Gompertz model for rice hulls, and the Orskov and McDonald (1979) did the same for the cassava chips. The lack of fit by the Mayer et al. (1994) test indicates that the model is unsuitable to represent the degradation kinetics of the feedstuffs in question.

The Gompertz model showed the highest MB for the feedstuffs rice hulls, turnip, and peach palm, with $6.0,0.5$, and $0.67 \%$, respectively, while for sugarcane the highest mean bias was obtained with the logistic model (0.25\%). For the feedstuff cassava chips, the Orskov and McDonald (1979) model displayed the highest mean bias $(2.46 \%)$. Yungblut et al. (1981) stated that a mean bias lower than $10 \%$ in relation to the observed values is acceptable.

Table 4. Regression parameters, $\mathrm{P}$-value, mean bias (MB), concordance correlation coefficient (CCC), and mean squared prediction error (MSPE) among the values observed for cumulative gas production and those estimated by the different mathematical models with different feedstuffs.

\begin{tabular}{|c|c|c|c|c|c|c|c|}
\hline \multirow{2}{*}{ Parameter } & \multicolumn{7}{|c|}{ Models $^{\mathrm{a}}$} \\
\hline & 1 & 2 & 3 & 4 & 5 & 6 & 7 \\
\hline \multicolumn{8}{|c|}{ Rice hulls } \\
\hline Intercept & -0.005 & 0.086 & 0.017 & 0.030 & 0.226 & 0.220 & 0.035 \\
\hline Slope & 1.002 & 0.976 & 0.993 & 0.991 & 0.937 & 0.939 & 0.990 \\
\hline $\mathrm{R}^{2}$ & 0.999 & 0.998 & 0.998 & 0.998 & 0.985 & 0.991 & 0.998 \\
\hline $\mathrm{P}^{\mathrm{b}}$ & 0.937 & 0.064 & 0.784 & 0.690 & 0.087 & 0.028 & 0.603 \\
\hline MB & 0.000 & 0.001 & 0.000 & 0.000 & 0.002 & 0.002 & 0.000 \\
\hline $\mathrm{CCC}$ & 1.000 & 0.999 & 0.999 & 0.999 & 0.990 & 0.993 & 0.999 \\
\hline MSPE & 0.001 & 0.004 & 0.003 & 0.003 & 0.033 & 0.022 & 0.003 \\
\hline \multicolumn{8}{|c|}{ Sugarcane } \\
\hline Intercept & -0.236 & 0.001 & 0.952 & 0.002 & 2.337 & 1.980 & 0.952 \\
\hline Slope & 1.006 & 1.000 & 0.975 & 1.000 & 0.939 & 0.948 & 0.975 \\
\hline $\mathrm{R}^{2}$ & 0.997 & 0.978 & 0.938 & 0.999 & 0.885 & 0.902 & 0.938 \\
\hline $\mathrm{P}^{\mathrm{b}}$ & 0.902 & 1.000 & 0.918 & 0.997 & 0.757 & 0.791 & 0.918 \\
\hline MB & -0.003 & 0.007 & -0.052 & 0.000 & 0.191 & 0.141 & 0.059 \\
\hline $\mathrm{CCC}$ & 0.998 & 0.989 & 0.969 & 0.999 & 0.940 & 0.949 & 0.969 \\
\hline MSPE & 0.317 & 2.137 & 6.183 & 0.123 & 11.853 & 10.061 & 6.183 \\
\hline \multicolumn{8}{|c|}{ Cassava chips } \\
\hline Intercept & -0.709 & 0.000 & -0.004 & 0.000 & -1.593 & -0.840 & -5.585 \\
\hline Slope & 1.011 & 1.000 & 1.000 & 1.000 & 1.025 & 1.013 & 1.089 \\
\hline
\end{tabular}


continuation

\begin{tabular}{lccccccc}
$\mathrm{R}^{2}$ & 0.998 & 0.995 & 0.995 & 0.997 & 0.983 & 0.991 & 0.980 \\
$\mathrm{P}^{\mathrm{b}}$ & 0.503 & 1.000 & 1.000 & 1.000 & 0.730 & 0.848 & 0.084 \\
$\mathrm{MB}$ & -0.007 & -0.011 & -0.012 & -0.004 & -0.157 & -0.107 & -0.392 \\
$\mathrm{CCC}$ & 0.999 & 0.998 & 0.998 & 0.998 & 0.991 & 0.995 & 0.985 \\
MSPE & 0.669 & 1.903 & 1.903 & 0.124 & 6.926 & 3.756 & 10.880 \\
\hline \multicolumn{7}{c}{ Turnip by-product } \\
Intercept & -0.087 & -0.001 & 0.001 & -0.003 & 1.064 & 1.088 & -0.262 \\
Slope & 1.003 & 1.000 & 1.000 & 1.000 & 0.968 & 0.967 & 1.008 \\
$\mathrm{R}^{2}$ & 0.999 & 0.998 & 0.993 & 0.999 & 0.973 & 0.981 & 0.993 \\
$\mathrm{P}^{\mathrm{b}}$ & 0.941 & 1.000 & 1.000 & 1.000 & 0.716 & 0.608 & 0.928 \\
$\mathrm{MB}$ & -0.009 & -0.001 & 0.000 & -0.003 & -0.015 & -0.021 & -0.011 \\
$\mathrm{CCC}$ & 1.000 & 0.999 & 0.997 & 1.000 & 0.986 & 0.990 & 0.996 \\
MSPE & 0.078 & 0.168 & 0.549 & 0.046 & 2.269 & 1.623 & 0.567 \\
\hline & & & Peach palm by-product & & & \\
Intercept & -0.324 & -0.001 & 2.242 & 0.000 & 6.060 & 5.552 & 2.234 \\
Slope & 1.004 & 1.000 & 0.974 & 1.000 & 0.930 & 0.936 & 0.974 \\
$\mathrm{R}^{2}$ & 0.999 & 0.997 & 0.977 & 1.000 & 0.934 & 0.946 & 0.977 \\
$\mathrm{P}^{\mathrm{b}}$ & 0.919 & 0.999 & 0.776 & 1.000 & 0.517 & 0.506 & 0.778 \\
MB & -0.031 & 0.135 & 0.006 & 0.004 & -0.129 & -0.185 & 0.171 \\
CCC & 0.999 & 0.999 & 0.988 & 1.000 & 0.965 & 0.972 & 0.988 \\
MSPE & 0.752 & 1.407 & 12.497 & 0.179 & 37.832 & 30.725 & 12.494 \\
\hline
\end{tabular}

${ }^{a} 1$ = Two-pool logistic; $2=$ France et al. (1993); $3=$ Exponential; $4=$ Two-pool exponential; $5=$ Logistic; $6=$ Gompertz; 7 = Orskov and McDonald (1979)

${ }^{\text {b }} \mathrm{P}>0.1=$ Ho : $\beta 0=0$ e $\beta 1=1 ; \mathrm{P}<0.1=\mathrm{Ha}:$ non Ho.

When CCC was analyzed, all models showed values close to 1 , indicating a good fit to the observed values. The CCC is a good parameter to evaluate the precision of values estimated by models, however, in this work it was of little importance to define the best model, since all the models tested presented ideal CCC (1) or very close to this value.

Among the model evaluation indices, the MSPE contributed best to demonstrating the adjustment of the models. Of these, the two-pool models stood out, with the two-pool logistic model showing the lowest value for rice hulls and cassava chips, whereas the two-pool exponential model had the lowest MSPE for sugarcane, turnip, and peach palm.

The coefficient of determination as the only criterion in the evaluation of the models is not a good indicator of fit, since high coefficients can be seen in prediction models with limited efficiency (NOGUERA et al., 2004). Therefore, CCC, which evaluates the precision and accuracy of data simultaneously, and RMSP, which was the most sensitive to detect the differences between the tested models, were also used as indicators.

Comparing four one-pool models, Uckardes et al. (2013) concluded that the Orskov model was statistically the best, whereas the Gompertz model was not suitable to estimate the gas production data. In the current study, the Gompertz model was not adequate $(\mathrm{P}<0.1)$ to estimate the gas production values from rice hulls, turnip, or peach palm. The Orskov model, however, was unsuitable $(\mathrm{P}<0.1)$ to estimate the gas production values from cassava 
chips, and showed higher MSPE values than the two-pool models and than the France model did. It must be stressed that the Orskov model utilized by Uckardes et al. (2013) included two parameters that were not included in the present study (gas originating from soluble fraction and gas originating from potentially degradable insoluble fraction), which might have generated a better fit of the model.

The lowest MSPE were observed in the twopool logistic (rice hulls and cassava chips) and two-pool exponential (sugarcane, turnip, and peach palm) models. Both models generated curves for the rapidly and slowly fermentable carbohydrates. These gas production curves allow the analysis of data and the comparison of feedstuffs or characteristics of the fermentation environment and can provide useful information regarding the composition of the feedstuff and fermentability of the soluble and slowly fermentable fractions of the feedstuffs.

It is possible that exponential curves, such as that generated by the two-pool exponential model, are observed when gas production originating from DM is evaluated, due to the presence of soluble carbohydrates in the tested feedstuffs. However, the observation of exponential curves originating only from the fibrous carbohydrates of slow fermentation seems not to be biologically correct, given that they require hydration, adherence, and bacterial colonization, which are considered a lag time, until the increase in gas production.

Although the two-pool models were those that best fitted the observed values, the logistic model was the most suitable for two feedstuffs, whereas the exponential model was the most adequate for the three other feedstuffs. As stated by Uckardes and Efe (2014), the reaction of the model depends on the substrate used, and the model may show different performances when different feedstuffs are used. Thus, it may be necessary to choose an appropriate model for each situation.

In a study with incubation of sunflower and corn silages, Mello et al. (2008) tested different non-linear models and observed that the France model generated negative volumes in the first three hours of incubation, which is a biologically impossible finding, and the authors attributed this fact to the value of parameter $b$, which does not have a biological interpretation. Additionally, they observed that the Gompertz and simple logistic models overestimated the second point of inflection of the curve and underestimated the asymptotic phase after $144 \mathrm{~h}$. These authors concluded that the two-pool logistic model was the most efficient for showing an adequate curve in all incubation stages and for presenting more-relevant characteristics from the nutritional aspect, e.g., the generation of parameters derived from fibrous and non-fibrous carbohydrates. This observation is corroborated by the work of Krueger et al. (2010), who observed a decrease in the rate and volume of gas originating from fibrous carbohydrates when glycerol was included in alfalfa samples incubated in vitro. This information was only possible because of the use of a two-pool model; in this case, the two-pool logistic model.

When a simple regression was run between the obtained digestible NDFap values (with the IVDNDF data) and the values of the asymptote of the FC from the models of lower MSPE, i.e., those that best fitted the profiles of accumulation of gases in the feedstuffs, it was possible to note a biological relationship of this parameter (Figure 1). 
Figure 1. Relationship between the asymptote of the FC obtained by the models of lowest MSPE with dNDF.

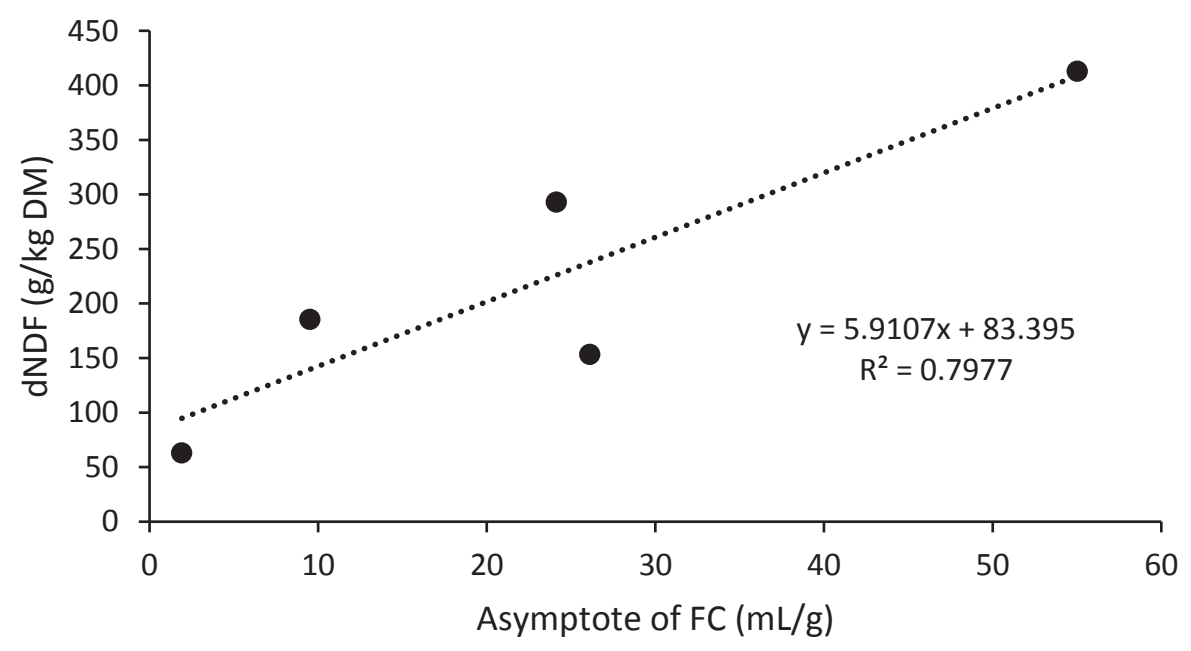

The figure 1 shows the high correlation $\left(\mathrm{R}^{2}=\right.$ 0.7977) between the production of gases resulting from the degradation of the FC and the digestible NDF content of each food. This observation is only possible from the use of two-pool models that results in parameters specific to each substrate (FC and NFC). The two-pool models consider that each substrate (phase) is degraded independently. This may account for differences in substrate accessibility due to particle hydration, microbial adherence and increase in the number of different microorganisms after latency time. Thus, the two-pool models besides presenting a better fit still provide a greater amount of parameters that can be used for a better evaluation of the foods tested by this technique.

\section{Conclusions}

For the tested feedstuffs, the two-pool models were the most suitable: the two-pool logistic model for rice hulls, and cassava chips, and the two-pool exponential model for sugarcane, turnip by-product, and peach palm by-product. These models also generate parameters of easy biological interpretation and of great nutritional value for the evaluation of feedstuffs used in ruminant nutrition.

\section{Acknowledgements}

The authors acknowledge the support by Fundação de Amparo à Pesquisa do Estado da Bahia, Universidade Estadual de Santa Cruz, Universidade Estadual do Sudoeste da Bahia and Instituto Nacional de Ciência e Tecnologia de Ciência Animal - INCT-CA.

\section{References}

ALMEIDA, F. M.; AZEVÊDO, J. A. G.; CABRAL, I. S.; PEREIRA, L. G. R.; ARAÚJO, G. G. L.; NOGUEIRA, A. S.; SOUZA, L. L.; OLIVEIRA, B. S.; VIEIRA, P. A. S. Kinetics in vitro of ruminal fermentation of cocoa husks subjected to alkali and heat treatment. Semina: Ciências Agrárias, Londrina, v. 36, n. 6, p. 3897-3908, 2015.

ASSOCIATION OF OFFICIAL ANALYTICAL CHEMISTS - AOAC. Official methods of analysis. $15^{\text {th }}$ ed. Arlington: Association of Official Analytical Chemists, 1990.

BENEDETI, P. D. B.; FONSECA, M. A.; SHENKORU, T.; MARCONDES, M. I.; PAULA, E. M.; SILVA, L. G.; FACIOLA, A. P. Does partial replacement of corn with glycerin in beef cattle diets affect in vitro ruminal fermentation, gas production kinetic, and enteric greenhouse gas emissions? Plos One, San Francisco, v. 13, n. 6, p. 1-18, 2018.

BIBBY, J.; TOUTENBURG, H. Prediction and improved estimation in linear models. New York: John Wiley \& 
Sons, 1977. $201 \mathrm{p}$.

COCHRAN, W. G.; COX, G. M. Experimental design. New York: John Wiley \& Sons, 1957. 615 p.

CORNU, A.; BESLE, J. M.; MOSONI, P.; GRENET, E. Lignin-carbohydrate complexes in forages: structure and consequences in the ruminal degradation of cell-wall carbohydrates. Reproduction Nutrition Development, Les Ulis, v. 34, n. 5, p. 385-398, 1994.

FONDEVILA, M.; BARRIOS, A. The gas production technique and its application to the study of the nutritive value of forages. Cuban Journal of Agricultural Science, San José de las Lajas, v. 35, n. 3, p. 187-196, 2001.

FRANCE, J.; DHANOA, M. S.; THEODOROU, M. K.; LISTER, S. J.; DAVIES, D. R.; ISAC, D. A model to interpret gas accumulation profiles associated with in vitro degradation of ruminant feeds. Journal of Theoretical Biology, San Diego, v. 163, n. 1, p. 99-111, 1993.

FRANCE, J.; LÓPEZ, S.; KEBREAB, E.; BANNINK, A.; DHANOA, M. S.; DIJKSTRA, J. A general compartmental model for interpreting gas production profiles. Animal Feed Science and Technology, Amsterdam, v. 123-124, n. 1, p. 473-485, 2005.

GETACHEW, G.; BLÜMMEL, M.; MAKKAR, H. P. S.; BECKER, K. In vitro gas measuring techniques for assessment of nutritional quality of feeds: a review. Animal Feed Science and Technology, Amsterdam, v. 72, n. 3, p. 261-281, 1998.

GETACHEW, G.; ROBINSON, P. H.; DEPETERS, E. J.; TAYLOR, S. J. Relationships between chemical composition, dry matter degradation and in vitro gas production of several ruminant feeds. Animal Feed Science and Technology, Amsterdam, v. 111, n. 1, p. 5771, 2004.

GROOT, J. C. J.; CONE, J. W.; WILLIAMS, B. A.; DeBersaques, F. M. A.; LANTINGA, E. A. Multiphasic analysis of gas production kinetics for in vitro fermentation of ruminant feeds. Animal Feed Science and Technology, Amsterdam, v. 64, n. 1, p. 7789, 1996.

HALL, M. B. Neutral detergent-soluble carbohydrates. Nutritional relevance and analysis. Gainesville: University of Florida, 2000. 39 p.

JIAO, P. X.; HE, Z. X.; DING, S.; WALKER, N. D.; CONG, Y. Y.; LIU, F. Z.; BEAUCHEMIN, K. A.; YANG, W. Z. Impact of strain and dose of live yeast and yeast derivatives on in vitro ruminal fermentation of a highgrain diet at two pH levels. Canadian Journal of Animal Science, Ottawa, v. 1, n. 1, p. 477-487, 2018.
KRIZSAN, S. J.; JANČÍK, F.; RAMIN, M.; HUHTANEN, P. Comparison of some aspects of the in situ and in vitro methods in evaluation of neutral detergent fiber digestion. Journal of Animal Science, Champaign, v. 91, n. 2, p. 838-847, 2013.

KRUEGER, N. A.; ANDERSON, R. C.; TEDESCHI, L. O.; CALLAWAY, T. R.; EDRINGTON, T. S.; NISBET, D. J. Evaluation of feeding glycerol on free-fatty acid production and fermentation kinetics of mixed ruminal microbes in vitro. Bioresource Technology, Lucknow, v. 101, n. 21, p. 8469-8472, 2010.

LI, M.; ZI, X.; ZHOU, H.; HOU, G.; CAI, Y. Effects of sucrose, glucose, molasses and cellulase on fermentation quality and in vitro gas production of king grass silage. Animal Feed Science and Technology, Amsterdam, v. 197, n. 1, p. 206-2012, 2014.

LICITRA, G.; HERNANDEZ, T. M.; VAN SOEST, P. J. Standardization of procedures for nitrogen fracionation of ruminant feeds. Animal Feed Science and Technology, Amsterdam, v. 57, n. 4, p. 347-358, 1996.

LIN, L. A. Concordance correlation coefficient to evaluate reprodutibility. Biometrics, Arlington, v. 45, n. 1, p. 255-268, 1989.

LÓPEZ, S.; DHANOA, M. S.; DIJKSTRA, J.; BANNINK, A.; KEBREAB, E.; FRANCE, J. Some methodological and analytical considerations regarding application of the gas production technique. Animal Feed Science and Technology, Amsterdam, v. 135, n. 1, p. 139156, 2007.

MAYER, D. G.; STUART, M. A.; SWAIN, A. J. Regression of real-world data on model output: an appropriate overall test of validity. Agricultural Systems, Montevideo, v. 45, n. 1, p. 93-104, 1994.

MELLO, R.; MAGALHÃES, A. L. R.; BREDA, F. C.; REGAZZI, A. J. Modelos para ajuste da produção de gases em silagens de girassol e milho. Pesquisa Agropecuária Brasileira, Brasília, v. 43, n. 2, p. 261-269, 2008.

MENKE, K. H.; STEINGASS, H. Estimation of the energetic feed value obtained from chemical analysis and gas production using rumen fluid. Animal Research and Development, Tübingen, v. 28, n. 1, p. 7-55, 1988.

MERTENS, D. R. Gravimetric determination of amylasetreated neutral detergent fiber in feeds with refluxing in beakers or crucibles: collaborative study. Journal of AOAC International, Arlington, v. 85, n. 6, p. 1217-1240, 2002.

NATIONAL RESEARCH COUNCIL - NRC. Nutrient requirements of dairy cattle. $7^{\text {th }}$ ed. Washington: The National Academies Pres, 2001. 381 p. 
NOGUERA, R. R.; SALIBA, E. O.; MAURICIO, R. M. Comparación de modelos matemáticos para estimar los parámetros de degradación obtenidos a través de la técnica de producción de gas. Livestock Research for Rural Development, Cali, v. 16, n. 11, p. 10-17, 2004. Available in: <http://www.lrrd.org/lrrd16/11/nogu 16086.htm>. Accessed at: 25 jan. 2018

ORSKOV, E. R.; MCDONALD, I. The estimation of protein degradability in the rumen from incubation measurements weighted according to rate of passage. Journal of Agricultural Science, Toronto, v. 92, n. 2, p. 499-503, 1979.

PELL, A. N.; SCHOFIELD, P. Computerized monitoring of gas production to measure forage digestion in vitro. Journal of Dairy Science, Champaign, v. 76, n. 4, p. 1063-1073, 1993.

RAMIN, M.; HUHTANEN, P. Development of an in vitro method for determination of methane production kinetics using a fully automated in vitro gas system - A modelling approach. Animal Feed Science and Technology, Amsterdam, v. 174, n. 3-4, p. 190-200, 2012.

RODRIGUES, M. A. M.; CONE, J. W.; FERREIRA, L. M. M.; BLOK, M. C.; GUEDES, C. V. M. Relationship between in situ degradation kinetics and in vitro gas production fermentation using different mathematical models. Animal Feed Science and Technology, Amsterdam, v. 151, n. 1-2, p. 86-96, 2009.

SCHOFIELD, P.; PITT, R. E.; PELL, A. N. Kinetics of fiber digestion from in vitro gas production. Journal of
Animal Science, Champaign, v. 72, n. 11, p. 2980-2991, 1994.

STATISTICAL ANALYSIS SYSTEM INSTITUTE - SAS INSTITUTE. System for Microsoft Windows: release 8.2. Cary: SAS Institute, 2008. CD-ROM.

TEDESCHI, L. O. Assessment of the adequacy of mathematical models. Agriculture System, Ithaca, v. 89, n. 2-3, p. 225-247, 2006.

UCKARDES, F. A modified Mitscherlich model and its degradation kinetics equations. Archiv Tierzucht, Dummerstorf, v. 56, n. 101, p. 1005-1013, 2013.

UCKARDES, F.; EFE, E. Investigation on the usability of some mathematical models in in vitro gas production techniques. Slovak Journal of Animal Science, Lužianky, v. 47, n. 3, p. 172-179, 2014.

UCKARDES, F.; KORKMAZ, M.; OCAL, P. Comparison of models and estimation of missing parameters of some mathematical models related to in situ dry matter degradation. The Journal of Animal \& Plant Sciences, Lahore, v. 23, n. 4, p. 999-1007, 2013.

VAN SOEST, P. J.; ROBERTSON, J. B. Analysis of forages and fibrous foods. Ithaca: Cornell University, 1985. $202 \mathrm{p}$.

YUNGBLUT, D. H.; STONE, J. B.; MACLEOD, G. K.; WILSON, G. F. The testing of several feed intake prediction equations using farm data. Canadian Journal of Animal Science, Ottawa, v. 61, n. 1, p. 159-164, 1981. 
